Ichiko Morita, head, Cataloging Department, Ohio State University Libraries, Columbus.

Emma Perry, director, Dillard University Library, New Orleans, Louisiana.

Gary Pitkin, director of university libraries, University of Northern Colorado, Greeley.

Roger Presley, head, Acquisitions Department, William Russell Pullen Library, Georgia State University, Atlanta.

Jane Robbins, director, University of Wisconsin/Madison SLIS.

Beth Shapiro, university librarian, Rice University, Fondren Library, Houston, Texas.
Sally Somers, assistant university librarian for technical services, Tulane University, Howard-Tilton Memorial Library, New Orleans, Louisiana.

Daniel Tsang, social sciences bibliographer, data services, University of California, Irvine.

Barbara von Wahlde, associate vice-president for University Libraries, State University of New York/Buffalo.

Betsy Wilson, head, Undergraduate Library, University of Illinois/Urbana-Champaign.

Joyce Wright, assistant to director of Departmental Library Services, University of Illinois/Urbana-Champaign.

\title{
ACRL seeks nominees for office
}

\section{The Association needs your help.}

ould you like to serve on the ACRL Board of Directors as vice-president/president-elect or seek office in an ACRL section? Would you like to nominate anyone else for such a position? If the answer is yes, here is what you need to do.

\section{ACRL Board of Directors}

The ACRL Appointments and Nominations Committee will be nominating candidates for ACRL vice-president/president-elect. The election will be held in the spring of 1992 . The winners will hold office beginning in the summer of 1992 . If you wish to be considered for nomination or if you would like to submit names for consideration, contact the chair of the committee Marion Reid, Director of Library Services, California State University, 820 W. Los Vallecitos, San Marcos, CA 92069, prior to ALA Annual Conference in Atlanta.

\section{ACRL section officers}

Candidates for vice-chair/chair-elect of ACRL sections are selected by the Nominating Committee of each section. If you would like to nominate someone or be nominated for vice-chair/chairelect of an ACRL section, contact the chair of the Nominating Committee for the appropriate sec- tion prior to ALA Conference in Atlanta. Other section offices, including secretary and memberat-large, may also be under consideration for this term of office, which would begin in the summer of 1992.

\section{Section Nominating Committee chairs}

Afro-American Studies Librarian Section. Curtis L. Kendrick, 1173 N. Carter Road, Decatur, GA 30030.

Anthropology and Sociology Section. Lynn M. Schmelz Keil, Librarian, Harvard University, Tozzer Library, 21 Divinity Ave., Cambridge, MA 02138 .

Arts Section. Roland C. Hansen, Readers Service Librarian, School of the Art Institute, Chicago, IL 60603.

Asian and African Section. ArlineZuckerman, University Research Librarian, University of California-Los Angeles, 405 Hilgard Ave., Los Angeles, CA 90024-1598.

Bibliographic Instruction Section. Esther S. Grassian, Reference Instruct. Librarian, College 
Library, University of California-Los Angeles, 405 Hilgard Ave., Los Angeles, CA 90024-1450.

College Libraries Section. Jonathan Lauer, Director, Murray Learning Resources Center, Messiah College, Grantham, PA 17027.

Community and Junior College Libraries Section. Susan M. Maltese, Cataloging Librarian, Oakton Community College Library, $1600 \mathrm{E}$. Golf Road, DesPlaines, IL 60016.

Education and Behavioral Sciences Section. Laurene E. Zaporozhetz, 1822 Thornwood Court, Zephyrhills, FL 33543.

Extended Campus Library Services Section. Mary Joyce Pickett, Director of Library Services, Illinois Benedictine College, Lownik Library, Lisle, IL 60532.

Law and Political Science Section. Patricia A. McCandless, Asst. Director Public Services, Ohio State University Libraries, 1858 Neil Avenue Mall, Columbus, $\mathrm{OH}$ 43210-1286.

Rare Books and Manuscripts Section. Peter M. VanWingen, Head, Reference Section-Rare
Books \& Special Collections, Library of Congress, 101 Independence Ave. S.E., Washington, DC 20540.

Science and Technology Section. Martin A. Kesselman, Science Librarian, Library of Science and Medicine, Rutgers University, P.O. Box 1029, Piscataway, NJ 08855-1029.

Slavic and East European Collections Section. Robert H. Burger, Associate Slavic Librarian, University of Illinois Library, 1408 W. Gregory Drive, Urbana, IL 61801.

University Libraries Section. Karen S. Seibert, Associate University Librarian for Public Services, University of North Carolina, Davis Library, Chapel Hill, NC 27599-3900.

Western European Specialists Section. John M. Cullars, University of Illinois at Chicago, University Library, P.O. Box 8198/MC234, Chicago, IL 60680 .

Women's Studies Section. Thura R. Mack, Reference Librarian, John C. Hodges Library, University of Tennessee, 1015 Volunteer Blvd., Knoxville, TN 37996-1000.

\section{Guide to the}

\section{Manuscript}

\section{Collections at the}

\section{Historical Society}

\section{of Pennsylvania}

Updated after 42 years, a major reference in American history...

- 2,170 collections of over 12 million documents summarized

- Manuscripts span more than 300 years of American history

- Handsome, hardbound volume, 700+ pages

- Many listings added, revised and corrected

- Name and subject indexing to Library of Congress standards

Order Now! For ordering information call 215/732-6201, or write to: Publications Dept./CRLN Historical Society of Pennsylvania 1300 Locust Street Philadelphia PA 19107 